\title{
Chapter 5 \\ Childlessness in East and West Germany: Long-Term Trends and Social Disparities
}

\author{
Michaela Kreyenfeld and Dirk Konietzka
}

\subsection{Introduction}

It is a well-established historical fact that childlessness has been a frequent phenomenon in Western Europe for centuries. Historical demography has found ample evidence that it was not uncommon for $20 \%$ or more of a cohort to never marry, and in most cases these unmarried people remained childless (Hajnal 1965). In Germany during the seventeenth and eighteenth centuries, the feudal order restricted the marriage behavior of the serfs, who needed to seek the consent of their "seigneurial lords" to get married (Mitterauer 1990). In the nineteenth century, when the feudal order had been overthrown in many of the German states, opportunities to get married improved. Nonetheless, the authorities continued to restrict access to marriage for people who were "considered to be in an unfavorable economic situation or otherwise socially undesirable" (Knodel 1967: 280; Matz 1980). The formation of the German Empire and the introduction of civil marriage in 1876 did not provide universal access to marriage, either. Marriage restrictions (Ehebeschränkungen) were not abolished in Germany until 1919 (Knodel 1967). In addition to the legal regulations that governed marriage and fertility behavior, economic and political conditions heavily influenced historical trends in childlessness. The significant events of the first half of the twentieth century that contributed to high levels of

\footnotetext{
M. Kreyenfeld $(\bowtie)$

Hertie School of Governance, Berlin, Germany

Max Planck Institute for Demographic Research, Rostock, Germany

e-mail: kreyenfeld@hertie-school.org

D. Konietzka

Department of Social Sciences, Braunschweig University of Technology,

Braunschweig, Germany

e-mail: d.konietzka@tu-braunschweig.de
} 
childlessness among the relevant cohorts were the Great Depression and the World Wars I and II (Schwarz 1991).

In Germany, as in other parts of Europe, a range of legal, economic, and social conditions shaped historical trends in childlessness. What makes the German case interesting is the more recent history since the mid-twentieth century, when Germany was divided into two opposing political systems. In the state-socialist German Democratic Republic (GDR), the centrally planned economy guaranteed stable and predictable employment paths. Furthermore, social and family policies that were often ridiculed in the West as being "pro-natalistic" encouraged early childbearing and the full-time integration of mothers into the labor market. West Germany's social policies were geared towards the male breadwinner model, and the trade unions adhered to the principle of family wages for male employees. Family policies, in particular the system of joint taxation and the coverage of non-working spouses in the public pension and health care systems, are the key characteristics of a regime that was never seriously interested in the integration of mothers into the labor market. Pro-natalism was rejected in West Germany, not only because it was misused during the Nazi period, but also because the government wanted to take a clear political stance against the pro-natalist orientation of East Germany's family policies. A statement by the first West German chancellor Konrad Adenauer reflects the attitudes towards family policies that were prevalent among West German politicians during that period: "Kinder bekommen die Leute immer" ("People will always have children").

When Adenauer made his famous statement, the fertility patterns in the two parts of Germany were quite similar. In the 1960s, the age at first birth was low, and the total fertility rate was around replacement level in both East and West Germany. However, the behavioral patterns in the two parts of the country started to diverge in the 1970s; and, from a cohort perspective, for women and men born in 1950 onwards. Among the cohorts born in 1950-1964, the share of women in East Germany who would remain childless held steady at around $10 \%$, whereas the share increased from $10 \%$ to around $20 \%$ in West Germany. The growth in childlessness in West Germany was accompanied by a steady rise in the age at first birth, a postponement of marriage, and an upsurge in cohabitation. Retrospectively, West Germany emerges as one of the "vanguard countries" in Europe in the trend towards high levels of childlessness. Other countries - and especially the countries of Southern Europe-started following this pattern later (see Sobotka in this volume).

The legacy of having lived under two very different regimes is still deeply entrenched in the fertility patterns and living arrangements that we observe in contemporary Germany. Compared to West Germans, East Germans are less likely to remain childless, are younger at first birth, and are far more likely to have children in a cohabiting union or as a single parent (Huinink et al. 2012). The correlation between socioeconomic characteristics and childlessness also differs between East and West. In East Germany, there are only small differences in childlessness rates by women's level of education; whereas in West Germany, highly educated women were far more likely than less educated women to remain childless. This elevated 
childlessness of the West German female academics has attracted considerable public and media attention, and was probably an important motivation for recent policy reforms, including the expansion of public childcare and the reform of the parental leave benefit system (Elternzeit). However, there is also evidence that behavioral patterns have shifted among the most recent cohorts, and that the educational disparities are narrowing for the younger cohorts of West German women.

In this paper, we aim to describe recent developments and to integrate them into a larger historical, economic, and social-political framework. The reminder of this paper is structured as follows. In the next section (Sect. 5.2) we present data from census and vital registration systems that elucidate long-term trends in childlessness in East and West Germany. In Sect. 5.3 we analyze the disparities in female childlessness between different socioeconomic groups using micro-census data. Due to the paucity of information on male fertility in the official data, we complement the official data with estimates on the number of children by gender based on social science survey data, and illustrate the major pathways that have led to childlessness among recent birth cohorts in Germany. In Sect. 5.4 we draw a conclusion.

\subsection{Childlessness in German Census and Micro-census Data: Long-Term Trends in Childlessness}

There is a dearth of official data on childlessness in (West) Germany. Census data, including the recent register based census of 2011, do not include the number of biological children ever born. Moreover, the only census that surveyed the number of children of married women is the one conducted in 1970. Although estimates of childlessness from these data may be too high because they do not include births to unmarried women, the census of 1970 is one of the rare sources that gives us an impression of the long-term trends in childlessness in West Germany. ${ }^{1}$ The estimates from these data show that childlessness was elevated for women born in the late nineteenth and early twentieth centuries. Further evidence that there were elevated levels of childlessness among the cohort born around 1900 comes from East German statistics (also Table 5.1). Unlike the censuses in West Germany, the East German census of 1981 collected the number of children ever born for the entire population, regardless of marital status. ${ }^{2}$ These data confirm that more than $20 \%$ of the East German women born in 1902-1909 were childless.

\footnotetext{
${ }^{1}$ Fertility estimates of census data have limitations. Most importantly, they do not cover the fertility behavior of the people who had died or had emigrated prior to the date of the interview. While this is a well-known problem of estimates based on census or micro-census data, it is aggravated for the West German census of 1970 because of the high death rates during World War II (including the mass killings of the Jewish population), large-scale resettlement (particularly from the former eastern German territories), and the high rates of emigration during and following the war.

${ }^{2}$ Like the West German census of 1970, the East German census of 1971 collected the number of children for married women only.
} 
Table 5.1 Childlessness of women in per cent, West German census of 1970 and East German census of 1981

\begin{tabular}{l|l|l|l|l|l|l|l|l|l}
\hline Cohorts & $\begin{array}{l}1895- \\
1904\end{array}$ & $\begin{array}{l}1905- \\
1909\end{array}$ & $\begin{array}{l}1910- \\
1914\end{array}$ & $\begin{array}{l}1915- \\
1919\end{array}$ & $\begin{array}{l}1920- \\
1924\end{array}$ & $\begin{array}{l}1925- \\
1929\end{array}$ & $\begin{array}{l}1930- \\
1934\end{array}$ & $\begin{array}{l}1935- \\
1939\end{array}$ & - \\
\hline $\begin{array}{l}\text { West } \\
\text { Germany }\end{array}$ & 33 & 33 & 28 & 25 & 25 & 25 & 22 & 18 & - \\
\hline Cohorts & - & $\begin{array}{l}1902- \\
1909\end{array}$ & $\begin{array}{l}1910- \\
1914\end{array}$ & $\begin{array}{l}1915- \\
1919\end{array}$ & $\begin{array}{l}1920- \\
1924\end{array}$ & $\begin{array}{l}1925- \\
1929\end{array}$ & $\begin{array}{l}1930- \\
1934\end{array}$ & $\begin{array}{l}1935- \\
1939\end{array}$ & $1940-$ \\
\hline $\begin{array}{l}\text { East } \\
\text { Germany }\end{array}$ & - & 22 & 17 & 17 & 18 & 16 & 12 & 10 & 9 \\
\hline
\end{tabular}

Note: West German data come from the Volkszählung 1970 BRD (own estimates conducted by Sebastian Böhm at GESIS, Mannheim). Only marital births were queried in these data. Furthermore, because foreigners were not asked in the census about their number of children, this group was eliminated from the analysis. The East German data come from the Volkszählung 1981 DDR. These data were provided upon request by Olga Pötzsch (Federal Statistical Office Germany)

The cohorts born around 1900 (in both East and West Germany) experienced economic deprivation in the aftermath of World War I and the Great Depression. While having experienced economic and social hardship certainly played a role in the high levels of childlessness in these cohorts, deprivation was not the only contributing factor. A potential factor that is seldom mentioned in this context is female emancipation. This is surprising, as the scholars of that time were very concerned about the growing share of women who were "earning their own livelihood" (Brentano 1910: 376). The cohorts born in the late nineteenth century would have entered adulthood during a period when new employment opportunities for young women were emerging in the growing service sector in the Weimar Republic of Germany (Zeeb 1915).

The most significant event that affected the life course of the following cohorts was World War II. As a result of the upheavals during and after the war-including resettlements, mass emigration, high rates of imprisonment, and the excess death rates among soldiers - the sex ratio among these cohorts was highly distorted. For example, for the West German cohort born in 1920, there were only 73 men to 100 women at age 36 (Human Mortality Database 2016). Thus, the lack of a marital partner was probably a key element in the family behavior of this generation of women.

Apart from censuses, long-term trends in childlessness are commonly generated based on vital statistics data. Among the prerequisites for using such data are that the biological order is available from the vital registration system, and that this information is collected for a sufficiently long period of time. Unfortunately, West German vital statistics do not fulfill these criteria. ${ }^{3}$ In the absence of better

\footnotetext{
${ }^{3}$ The vital statistics were not changed to include biological birth order in the registers until 2008. Since 2009, the new registration system has been fully implemented. Although this reform modernized German vital statistics system, it does not enable the system to generate cohort estimates of childlessness until several decades in the future. In order to estimate the share of ultimate childlessness by birth cohort among women, order-specific birth information for the reproductive histories of an entire cohort must be collected. This means that the German registration system will produce the first estimates of childlessness for the cohorts born in 1994 who reached age 15 in
} 
Table 5.2 Number of children by birth cohorts of women (in per cent) and mean number of children. Vital statistics (East Germany) and combined vital statistics and survey data (West Germany)

\begin{tabular}{l|c|c|c|c}
\hline Cohorts & 1940 & 1945 & 1950 & 1955 \\
\hline East Germany & 11 & 8 & 7 & 8 \\
\hline Childless & 26 & 29 & 30 & 27 \\
\hline One child & 35 & 42 & 47 & 48 \\
\hline Two children & 28 & 21 & 16 & 18 \\
\hline Three and more children & 100 & 100 & 100 & 100 \\
\hline Total & $\mathbf{1 . 9 8}$ & $\mathbf{1 . 8 7}$ & $\mathbf{1 . 7 9}$ & $\mathbf{1 . 8 4}$ \\
\hline Mean number of children & \multicolumn{1}{|l}{} & & \\
\hline West Germany & 11 & 13 & 14 & 19 \\
\hline Childless & 26 & 30 & 31 & 27 \\
\hline One child & 34 & 35 & 35 & 36 \\
\hline Two children & 29 & 22 & 20 & 18 \\
\hline Three and more children & 100 & 100 & 100 & 100 \\
\hline Total & $\mathbf{1 . 9 7}$ & $\mathbf{1 . 7 8}$ & $\mathbf{1 . 7 0}$ & $\mathbf{1 . 6 2}$ \\
\hline Mean number of children & & & & \\
\hline
\end{tabular}

Source: For East Germany, data were provided upon request by Jürgen Dorbritz (Bundesinstitut für Bevölkerungsforschung). Data for West Germany are estimates based on Kreyenfeld (2002)

Note: For the West German 1955 cohort, the estimates are up to age 40 only

alternatives, researchers had estimated childlessness by combining survey and vital statistics data (Birg et al. 1990; Kreyenfeld 2002). For East Germany, superior data are available, as the vital statistics of the GDR had included biological birth order. It is one of the ironies of German unification that this practice was discontinued in 1990 because East Germany had to adopt the German Federal Statistics Law. Nevertheless, during its 40 years of existence, the vital statistics of the GDR produced data for a period that is long enough to allow us to calculate the share of ultimately childless women for several cohorts of women. These data, together with the estimates from the West German data, are presented in Table 5.2. They show that in East Germany $11 \%$ of the 1940 cohort were childless, and that this share declined to less than $10 \%$ for the subsequent cohorts. In West Germany, by contrast, $11 \%$ of the 1940 cohort remained childless, but childlessness increased gradually among the subsequent cohorts, reaching $19 \%$ for the 1955 cohort.

Micro-census data are a further source for generating fertility indicators, including the prevalence of childlessness by birth cohorts of women (and, ideally, of men). ${ }^{4}$ In the German micro-census, women aged 15-75 are asked every 4 years

2009, when the reform was first implemented. Thus, the first official estimates on ultimate childlessness from the German registration system will be generated in 2043, when this birth cohort reaches age 49.

${ }^{4}$ In Germany, the questionnaire of the micro-census is governed by law, and requires the approval of the German Bundesrat. The inclusion of the question on the number of children was preceded by a lengthy debate over the sensitivity of the item. Among the arguments that were made against 
how many biological children they have..$^{5}$ The question about the number of children was included in the micro-census for the first time in 2008, and for the second time in 2012 (see also: Bujard 2015; Bujard et al. 2015; Dorbritz 2015; Naderi 2015). The parity distribution that is generated using these data is displayed in Table 5.2. The table shows that childlessness has been rising in West Germany starting with the 1940s cohorts. Of the most recent cohorts, those born in 19651969, $22 \%$ have remained childless, which suggests that childlessness has increased steadily starting with the cohorts born in the 1940s. By contrast, in East Germany female childlessness levels stalled for the 1940-1959 cohorts, and increased only slightly thereafter. Hence, childlessness levels in East Germany are still substantially lower than those of West Germany. However, the increase in childlessness among the recent birth cohorts indicates that the differences in the birth patterns of the two parts of Germany have become smaller.

Examining the childlessness trends in East Germany is instructive when seeking to understand how radical changes on the macro level transfer into cohort-specific behavioral patterns. The cohorts who were most affected by the economic and political transformation in the aftermath of unification were those born between 1965 and 1969. They experienced the early stages of their employment careers in the 1990s, and thus during the period when the East German economy was being privatized. In the course of privatization, many factories were closed, unemployment was high, and work schedules were reduced. Yet despite these challenging economic conditions, only $17 \%$ of these cohorts were childless; a considerably smaller share than that of their West German counterparts. One explanation for this relatively low level of childlessness is that many of the women in these cohorts had their first child before German unification; while a second explanation is that these cohorts were still in the mid- or late twenties when the Berlin Wall came down, and could thus delay childbearing without getting to close to the biological limits of fertility. The East German case illustrates that even severe economic upheavals do not necessary lead to an increase in childlessness, and that the extent to which economic conditions affect childlessness depends on the "fertility regime". Since the fertility regime of East Germany was characterized by universal and early childbearing, childless women had the "biographical leeway" to postpone childbearing until conditions improved.

the inclusion of this question were, for example, that the micro-census is a household survey. The opponents also argued that during the interview situation a man (or a woman) may be forced to report having a child whom he had, up to that point, successfully concealed from his spouse. Still other opponents raised concerns that a question on the number of children would create distress for people with deceased children. A further argument was that a woman who had deposited her child in a "baby hatch" would be forced to report a birth she would like to keep anonymous.

${ }^{5}$ Unfortunately, the question on the number of children is one of the few non-obligatory questions in the German micro-census. Unlike most of the other questions, which respondents are required to answer by law, people are free to choose whether to provide this information. Missing cases were largely imputed by the German statistical office, but sensitivity analyses of competing imputation methods have, unfortunately, never been conducted. Nevertheless, compared to estimates from social science surveys, estimates from micro-census data are presumably relatively reliable due to the high case numbers and the low unit non-response of these data. 


\subsection{Social Disparities in Childlessness}

\subsubsection{Childlessness by Level of Education}

In the public debate, concerns have been raised about the elevated rates of childlessness among female university graduates in West Germany. Some of these estimates-e.g., that $40 \%$ or more of these women are childless (see e.g.: Der Spiegel 2005) - are greatly exaggerated. Nevertheless, there is firm evidence from multiple sources that female university graduates in West Germany are more likely to remain childless than their less educated counterparts (see e.g., Duschek and Wirth 2005; Schmitt and Winkelmann 2005). In Table 5.3 we provide new evidence on female childlessness by level of education in East and West Germany based on an analysis of data from the German micro-census of 2012. Migrants have been omitted from

Table 5.3 Number of children by birth cohorts of women (in per cent) and mean number of children. German micro-census 2012

\begin{tabular}{|c|c|c|c|c|c|c|}
\hline & $\begin{array}{l}1940- \\
1944\end{array}$ & $\begin{array}{l}1945- \\
1949\end{array}$ & $\begin{array}{l}1950- \\
1954\end{array}$ & $\begin{array}{l}1955- \\
1959\end{array}$ & $\begin{array}{l}1960- \\
1964\end{array}$ & $\begin{array}{l}1965- \\
1969^{\mathrm{a}}\end{array}$ \\
\hline \multicolumn{7}{|l|}{ Germany } \\
\hline Childless & 12 & 13 & 15 & 18 & 20 & 22 \\
\hline 1 child & 25 & 27 & 27 & 25 & 24 & 25 \\
\hline 2 children & 40 & 40 & 41 & 40 & 39 & 37 \\
\hline 3 and more & 24 & 20 & 17 & 18 & 17 & 16 \\
\hline Total & 100 & 100 & 100 & 100 & 100 & 100 \\
\hline $\begin{array}{l}\text { Mean number } \\
\text { of children }\end{array}$ & 1.89 & 1.76 & 1.69 & 1.67 & 1.60 & 1.54 \\
\hline \multicolumn{7}{|l|}{ East Germany } \\
\hline Childless & 10 & 10 & 10 & 10 & 13 & 17 \\
\hline 1 child & 28 & 30 & 29 & 27 & 32 & 34 \\
\hline 2 children & 40 & 44 & 47 & 48 & 43 & 36 \\
\hline 3 and more & 22 & 17 & 14 & 16 & 13 & 13 \\
\hline Total & 100 & 100 & 100 & 100 & 100 & 100 \\
\hline $\begin{array}{l}\text { Mean number } \\
\text { of children }\end{array}$ & 1.87 & 1.73 & 1.72 & 1.75 & 1.61 & 1.52 \\
\hline \multicolumn{7}{|l|}{ West Germany } \\
\hline Childless & 12 & 14 & 17 & 20 & 22 & 24 \\
\hline 1 child & 23 & 27 & 26 & 24 & 22 & 23 \\
\hline 2 children & 40 & 39 & 39 & 38 & 38 & 37 \\
\hline 3 and more & 25 & 21 & 19 & 19 & 18 & 17 \\
\hline Total & 100 & 100 & 100 & 100 & 100 & 100 \\
\hline $\begin{array}{l}\text { Mean number } \\
\text { of children }\end{array}$ & 1.90 & 1.76 & 1.68 & 1.64 & 1.59 & 1.54 \\
\hline
\end{tabular}

Note: East Germany, including East Berlin

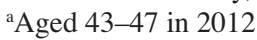

Course: Micro-census 2012 (own estimates) 
this analysis because migration background is an important confounder in the association between education and fertility (see also Naderi 2015, and Table A2 in the Appendix for a calculation by migrant status). We distinguish between women with a tertiary degree, with a vocational training degree, and with none of these certificates. This distinction differs slightly from the ISCED classification that is commonly used in cross-national comparisons, but it is particularly well suited for mapping differential labor market opportunities in Germany, which tend to reward tertiary education and vocational education and training more than general secondary education (Konietzka 2003).

The findings displayed in the table support the notion that childlessness levels are indeed high among female university graduates, especially among the cohorts born in 1940-1944: $25 \%$ of the women with tertiary education, but only $13 \%$ of those with a vocational training degree and $9 \%$ of those without a degree remained childless. It is, however, important to note that only a small fraction of the women in these cohorts received tertiary education (see Table A1 in the Appendix), whereas the women of the following cohorts greatly profited from the educational expansion in Germany. Even though in all of the cohorts women with a university degree were the most likely to remain childless, the table shows significant changes in this pattern over time. Most importantly, it is clear that for the youngest cohorts the levels of childlessness among university educated women have not been increasing, even though the levels have been rising among the other educational groups, and especially among those who did not earn a degree. This means that educational differences in levels of childlessness are narrowing over time. The West German cohort born in 1965-1969 will probably be the first for whom female education explains only a very small share of the differences in childlessness at later ages.

In East Germany, the differences in childlessness rates by level of education are small. We even see that women without a degree are more likely to remain childless than women with a university or vocational training degree. It is important to note, however, that East Germany was a much more homogeneous society than West Germany. On the one hand, the state-socialist policies pushed people to earn at least a vocational training degree. Thus, the share of individuals who never earned a degree was very low, and represented a selective group of people who probably also suffered from health impairments (see Table A1 in the Appendix). On the other hand, access to university education was highly rationed and directed by the state authorities. Despite the selectivity of the university graduates in the older East German cohorts, levels of childlessness were very low among female university graduates. Even among the 1965-1969 cohorts, East German women with a university degree are less likely to be childless than less educated West German women.

Table 5.5 reports the results from analyses based on alternative operational definitions of education. In order to guarantee significant case numbers of individual categories, we grouped the 1960-1964 and 1965-1969 cohorts into a single group and restricted the analysis to the West German sample. The upper part of the table contains the results by whether the woman has a vocational or a university degree. Similar to the results from Table 5.4, educational differences are small. When the analysis of women's childlessness is based on their school-leaving certificates (sec- 
Table 5.4 Childlessness of women by birth cohorts and education (in per cent). Women without migration background. German micro-census 2012

\begin{tabular}{|c|c|c|c|c|c|c|}
\hline & $\begin{array}{l}1940- \\
1944\end{array}$ & $\begin{array}{l}1945- \\
1949\end{array}$ & $\begin{array}{l}1950- \\
1954\end{array}$ & $\begin{array}{l}1955- \\
1959\end{array}$ & $\begin{array}{l}1960- \\
1964\end{array}$ & $1965-1969^{a}$ \\
\hline \multicolumn{7}{|l|}{ West Germany } \\
\hline No degree & 9 & 12 & 15 & 18 & 21 & 25 \\
\hline Vocational degree & 13 & 14 & 17 & 19 & 21 & 22 \\
\hline Tertiary degree & 25 & 24 & 28 & 31 & 32 & 31 \\
\hline \multicolumn{7}{|l|}{ East Germany } \\
\hline No degree & 9 & 13 & 17 & 26 & 28 & 29 \\
\hline Vocational degree & 9 & 9 & 8 & 8 & 10 & 14 \\
\hline Tertiary degree & 13 & 16 & 13 & 14 & 18 & 23 \\
\hline
\end{tabular}

Note: aged 43-47 in 2012. Women with a migrant background were excluded from this table Course: Micro-census 2012 (own estimates)

Table 5.5 Childlessness in per cent. West German women without a migration background. Cohorts 1960-1969

\begin{tabular}{l|l}
\hline Vocational or university education \\
\hline No degree & 23 \\
\hline Vocational degree & 22 \\
\hline University degree & 32 \\
\hline School level degree & 20 \\
\hline Low (Hauptschule or less) & 22 \\
\hline Medium (Realschule) & 30 \\
\hline High (Fachhochschulreife, Abitur) & \\
\hline Combined degrees & 22 \\
\hline No degree \& low schooling & 21 \\
\hline No degree \& medium schooling & 32 \\
\hline No degree \& high schooling & 19 \\
\hline Vocational degree \& low schooling & 22 \\
\hline Vocational degree \& medium schooling & 29 \\
\hline Vocational degree \& high schooling & 32 \\
\hline University degree &
\end{tabular}

Source: Micro-census 2012 (own estimates)

ond part of the table), we find a clear negative educational gradient. In the last part of this table, we have combined the two types of operational definitions of education into seven different categories. This system of classification results in a very uneven pattern: in addition to women with a university degree, women whose highest degree was the Abitur are found to have high levels of childlessness. It is likely that the educational careers of women who have the Abitur, but who never earned a vocational training or university degree, were disrupted. These women may have entered and exited education, and never settled into a stable employment career, and for this reason remained childless. 
Table 5.6 Childlessness by education. West German Cohorts 1971-1973. German Family Panel (pairfam). Column per cent

\begin{tabular}{l|l|l}
\hline & Women & Men \\
\hline No degree & 20 & 36 \\
\hline Vocational degree & 25 & 36 \\
\hline University degree & 25 & 28 \\
\hline All & 25 & 33 \\
\hline Sample size & 800 & 617
\end{tabular}

Note: The sample includes women and men aged 40 and older at the time of the interview. Migrants are excluded from this analysis. Estimates are weighted by the combined designs and post-stratification weight d1ca1weight

Source: German Family Panel pairfam, waves 1-6 (years 2008/2009-2013/2014)

\subsubsection{Childlessness Among Men and Women}

To further explore the socioeconomic gradient in childlessness, we analyzed estimates from the German Family Panel pairfam, the results of which are shown in Table 5.6 (for details on this data see: Huinink et al. 2011; Kreyenfeld et al. 2012). The sample was restricted to West German men and women of the 1971-1973 cohorts who were at least 40 years old at the last interview (on average age 41) and who were born in Germany. Although the German Family Panel oversamples East Germans, the number of childless East Germans of these cohorts is too small for a meaningful investigation. Thus, as a separate analysis of the East German patterns was not feasible using these data, the table shows the results for the West German respondents only. The findings presented in the table only partially support the prior evidence of the micro-census, as women without a degree are found to be substantially less likely to remain childless than the other two groups. This difference may stem from the different operational definitions of education in these data. It should also be noted that these cohorts are, on average, age 41 at the time of censoring. It seems likely that the highly educated have a greater probability of having children at higher ages; thus, the differences in childlessness levels between the less educated and the highly educated may narrow further over time.

With regard to gender differences in childlessness, we observe that $25 \%$ of the women, but $33 \%$ of the men are childless at age 41 (which is the average age at censoring in the sample). It is well known that men start the family formation process later than women, and the biological limits of fertility are often considered to be less fixed for men than for women. Thus, there is every reason to believe that the male respondents are more likely than the female respondents to have children past the date of the interview. Other potential explanations for the gender difference are that childless men are not well covered in the survey data, and that when they are covered they are more likely than women to provide faulty reports on their number of children (Rendall et al. 1999). Because we have no external sources to validate male fertility, we can only raise this concern, but have no remedy to cure it. More clarity exists regarding the educational gradient in childlessness. The findings dis- 
played in the table suggest that there is a negative educational gradient in childlessness among men. While a large share of the men with a vocational degree or with no degree have no biological children, the percentage of university educated men who are childless is substantially lower.

Unlike other types of demographic behavior, such as divorce, teenage pregnancy, or non-marital childbearing, childlessness cannot be inherited, and thus passed on to the next generation. However, the number of brothers and sisters a person has may influence his or her ideas about family behavior. Thus, in Table 5.7 we display the results of an analysis of the degree of childlessness by the number of siblings. We find that there is indeed a strong association between these two parameters. Women and men who come from larger families are less likely to remain childless than women and men who were raised as only children. This evidence suggests that a decline in the number of children in each family could result in an increase in childlessness among the next generation. However, this is only an association that does not control for the many characteristics that may be correlated with the number of siblings, such as parental education and the value orientations of the parents and their children.

A characteristic that must be considered in this context is religious affiliation, which has been shown in prior investigations to explain fertility differences in contemporary as well as in past societies (Berghammer 2012). The data from the German Family Panel support this association (see Table 5.8). If we look at the female respondents, we can see that $32 \%$ of those who have no religious affiliation, but just $23 \%$ of those who have a religious affiliation, are childless. A more subtle analysis in a multivariate framework (not shown here) indicates that the effect of religiosity is stable to the inclusion of further covariates, such as education and number of siblings. For men, the differences in levels of childlessness by religiosity are smaller, and insignificant. An aspect that this simple cross-tabulation does not explore is the interaction of having children and religious practices and affiliations over the life course (for a longitudinal analysis of religiosity in Germany, see Lois 2010).

Table 5.7 Childlessness by number of siblings. West German cohorts 1971-1973. German Family Panel (pairfam). Column per cent

\begin{tabular}{l|l|c}
\hline & Women & Men \\
\hline No siblings & 33 & 44 \\
\hline 1 sibling & 23 & 35 \\
\hline 2 siblings & 32 & 31 \\
\hline 3 and more siblings & 16 & 25 \\
\hline Sample size & 800 & 618
\end{tabular}

Note: The sample includes women and men aged 40 and older at the time of the interview. Migrants are excluded from this analysis. Estimates are weighted by the combined designs and post-stratification weight d1ca1 weight

Source: German Family Panel pairfam, waves 1-6 (years 2008/2009-2013/2014) 
Table 5.8 Childlessness by religious affiliation. West German cohorts 1971-1973. German Family Panel (pairfam). Column per cent

Table 5.9 Childlessness by marital status. West German cohorts 1971-1973. German Family Panel (pairfam)

\begin{tabular}{l|l|l}
\hline & Women & Men \\
\hline Religious affiliation & 23 & 32 \\
\hline $\begin{array}{l}\text { No religious } \\
\text { affiliation }\end{array}$ & 32 & 36 \\
\hline Sample size & 801 & 618 \\
\hline
\end{tabular}

Note: The sample includes women and men aged 40 and older at the time of the interview. Migrants are excluded from this analysis. Estimates are weighted by the combined designs and post-stratification weight d1calweight

Source: German Family Panel pairfam, waves 1-6 (years 2008/2009-2013/2014)

\begin{tabular}{l|l|c}
\hline & Women & Men \\
\hline Never married & 68 & 77 \\
\hline Married & 12 & 13 \\
\hline $\begin{array}{l}\text { Divorced or } \\
\text { widowed }\end{array}$ & 21 & 16 \\
\hline Sample size & 800 & 611 \\
\hline
\end{tabular}

Note: The sample includes women and men aged 40 and older at the time of the interview. Migrants are excluded from this analysis. Estimates are weighted by the combined designs and poststratification weight d1calweight

Source: German Family Panel pairfam, waves 1-6 (years 2008/2009-2013/2014)

In most cases, childlessness is not the result of a single decision, but is instead the outcome of an accumulation of actions and decisions in the various domains of the life course (Hagestad and Call 2007; Jalovaara and Fasang 2015). In addition to his or her employment and educational careers, an individual's partnership process is likely to affect whether he or she remains childless. Thus, in Table 5.9 we show the results of the analysis on levels of childlessness by marital and partnership status. It is hardly surprising that men and women who were single at the time of the interview have a much higher probability of being childless than married women and men. Marriage and childbearing are "tied events" (Hoem and Kreyenfeld 2006; Nave-Herz 2006) in West Germany, and people often get married in anticipation of having children. While it may seem obvious that there is a strong correlation between marriage and childlessness, it is surprising to see how closely the two are correlated: $12 \%$ of the married women and $13 \%$ of the married men are childless, whereas among the never married, about $75 \%$ of the men and almost $70 \%$ of the women are childless. 


\subsubsection{Pathways to Childlessness}

Marriage and the partnership status in the abovementioned analyses refer to the characteristics of the respondent at the date of the last interview. Because parents may be more hesitant to dissolve a union than childless couples, being single at the time of the interview may not be the cause, but the consequence of not having children. In order to explore how the marital and partnership trajectories relate to later life childlessness, we present sequence index plots in the following (Abbott 1995). To improve the comparability of the plots, we have drawn a sample of men, women, childless individuals, and individuals with children. All four groups contain 50 randomly selected cases. Their union histories are displayed in Fig. 5.1. In the figure we distinguish between episodes (a) of being single; (b) of being in a cohabiting union without being married; (c) of being separated, widowed, or divorced; and (d) of being in a marital union, irrespective of whether the partner lives in the same household.

The figure shows that childlessness is closely related to the individual's partnership biography. The childless women, and particularly the childless men, were single for much of their twenties and thirties. Only a small fraction of the childless men have been married over a longer period of time (for a detailed study on childlessness of married couples, see Rupp 2005). In addition to observing that a large share of the childless individuals are permanently single, we can see that a large fraction of the childless men and women moved in and out of a (cohabiting or marital) union. Overall, there seem to be two dominant pathways to childlessness: having a turbulent partnership biography and being permanently single. The latter pathway is more typical for men than for women.

While the patterns for childless men and women differ, this is not the case for men and women with children. The primary difference between the sexes in this context is that men tend to enter cohabitation later than women. For both sexes, periods of cohabitation are typically of short duration. The large majority of the men and women who eventually have children turn their cohabitation into a marriage in West Germany.

\subsection{Summary}

In this paper, we have provided an overview of the long-term trends in childlessness in East and West Germany. We have also explored the socioeconomic differences in childlessness and how they have changed over time. For East Germany, we find only little differences in childlessness by female education. East German women of the birth cohorts 1940-1969 mostly had their children before unification when childbearing was almost universal and women integrated into the labor market full-time. In West Germany, there is a strong educational gradient of female childlessness. University educated women are substantially more likely to remain childless than 


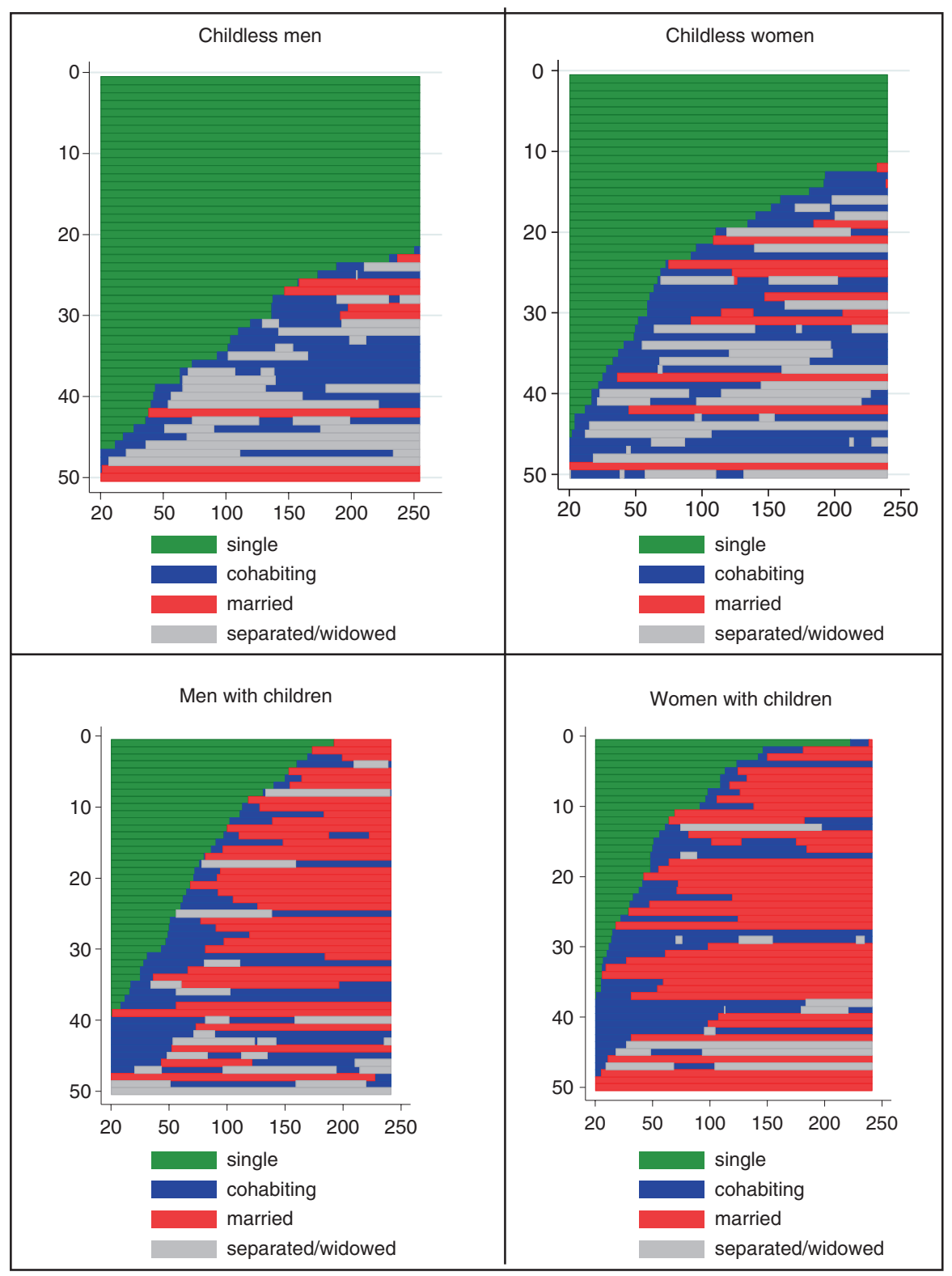

Fig. 5.1 Sequence index plots of the partnership trajectories for West German men and women (x-axis: time since age 20 in months, y-axis: number of cases) 
medium or lowly educated women. A very significant development is, however, the narrowing of childlessness by education among the recent female birth cohorts in West Germany. While childlessness among the highly educated has stalled for the recent cohorts, it has continued to increase among the other educational groups, and particularly among women who never earned a university or a vocational training degree. A possible explanation for this finding is that highly educated women have profited more than less educated women from recent policy reforms, such as the expansion of public day care and the reform of the parental leave benefit system in 2007. It may also be the case that less educated women are gradually losing out on the partner market. This finding would appear to confirm evidence from other countries that the lack of a partner often leads to childlessness among less educated women (Jalovaara and Fasang 2015, see also Berrington in this volume). If this interpretation was correct, it would stand in contrast to prior speculations that the lack of a partner was the typical pathway into childlessness for the highly educated women in Germany (Der Spiegel 2005).

The investigations that have been presented in this paper have many limitations. One of the limitations is that findings were sensitive to the classification of education. Moreover, education was only measured at interview and did not capture the educational biographies that may or may not have led to a specific educational outcome. Related to that we have pointed out the problems of correctly classifying a person who got a high school degree (Abitur), but never continued to receive a university or vocational training certificate. These people are very often childless, most likely because of their disruptive educational careers.

Some of the findings that we have generated in this paper were hard to interpret. In particular, it seems difficult to understand why childlessness is continuously increasing among West German women with a vocational training degree. More nuanced analyses by type of education would certainly lead to a better understanding for the elevated childlessness among this large group of women (see Neyer et al. in this volume for analyses by field of education using Swedish and Austrian data). We also explored pathways into childlessness my means of sequence analysis in this paper. It was shown that permanent singlehood as well as turbulences in the partnership history are strongly associated with childlessness. However, this part of the analysis remained very explorative. The results confirm that a partnership is a prerequisite for having children, but the causal direction, in particular how fertility preferences influence partnership dynamics, was not explored. 


\section{Appendix}

Table A1 Level of education by birth cohorts (in per cent). Women without migration background. German micro-census 2012

\begin{tabular}{|c|c|c|c|c|c|c|}
\hline & $\begin{array}{l}1940- \\
1944\end{array}$ & $\begin{array}{l}1945- \\
1949\end{array}$ & $\begin{array}{l}1950- \\
1954\end{array}$ & $\begin{array}{l}1955- \\
1959\end{array}$ & $\begin{array}{l}1960- \\
1964\end{array}$ & 1965-1969* \\
\hline \multicolumn{7}{|l|}{ West Germany } \\
\hline No degree & 30 & 23 & 18 & 14 & 13 & 11 \\
\hline Vocational degree & 63 & 68 & 69 & 72 & 72 & 73 \\
\hline Tertiary degree & 7 & 9 & 13 & 14 & 15 & 17 \\
\hline Total & 100 & 100 & 100 & 100 & 100 & 100 \\
\hline
\end{tabular}

East Germany

\begin{tabular}{l|r|r|r|r|r|r}
\hline No degree & 12 & 7 & 6 & 5 & 4 & 4 \\
\hline Vocational degree & 79 & 82 & 78 & 79 & 80 & 80 \\
\hline Tertiary degree & 9 & 11 & 15 & 15 & 16 & 16 \\
\hline Total & 100 & 100 & 100 & 100 & 100 & 100
\end{tabular}

Source: Micro-census 2012 (own unweighted estimates)

Note: *Aged 43-47 in 2012

Table A2 Childlessness of women by birth cohorts and education (in per cent). All women (including those without migration background.) German micro-census 2012

\begin{tabular}{l|l|l|l|l}
\hline & & \multicolumn{2}{|l|}{ West Germans } & East Germans \\
\cline { 3 - 5 } & All & $\begin{array}{l}\text { No migration } \\
\text { background }\end{array}$ & $\begin{array}{l}\text { Migration } \\
\text { background }\end{array}$ & $\begin{array}{l}\text { No migration } \\
\text { background }\end{array}$ \\
\hline No degree & 17 & 23 & 8 & 28 \\
\hline Vocational degree & 19 & 22 & 12 & 12 \\
\hline Tertiary degree & 28 & 32 & 21 & 21 \\
\hline
\end{tabular}

Source: Micro-census 2012 (own un-weighted estimates)

Note: Due to the small numbers of migrants in East Germany, we did not distinguish the East German sample by migration background

\section{Literature}

Abbott, A. (1995). Sequence analysis: New methods for old ideas. Annual Review of Sociology, 21, 93-113.

Berghammer, C. (2012). Family life trajectories and religiosity in Austria. European Sociological Review, 28, 127-144.

Birg, H., Filip, D., \& Flöthmann, E.-J. (1990). Paritätsspezifische Kohortenanalyse des generativen Verhaltens in der Bundesrepublik Deutschland nach dem 2. Weltkrieg. IBS-Materialien 16.

Brentano, L. (1910). The doctrine of Malthus and the increase of population during the last decades. The Economic Journal, 20, 371-393. 
Bujard, M. (2015). Kinderlosigkeit in Deutschland: Wie interagieren Bildung, Wohnort, Migrationshintergrund, Erwerbstätigkeit und Kohorte? Zeitschrift für Familienforschung, 3, 255-269.

Bujard, M., Dorbritz, J., Herter-Eschweiler, R., \& Lux, L. (2015). Das unterschätzte Potenzial hoher Fallzahlen - Stärken und Limitierungen des Mikrozensus am Beispiel von Fertilitätsanalysen. Zeitschrift für Familienforschung, 3, 343-872.

Der Spiegel. (2005). Über 40 Prozent kinderlos: "Akademikerinnen finden oft keinen Partner". (07.09.2005). Accessed 15 Jan 2016.

Dorbritz, J. (2015). Paritätsverteilungen nach Geburtsjahrgängen, Lebensformen und Bildung bei besonderer Beachtung von Kinderlosigkeit und Kinderreichtum: Eine demografischsoziologische Analyse. Zeitschrift für Familienforschung, 3, 297-321.

Duschek, K.-J., \& Wirth, H. (2005). Kinderlosigkeit von Frauen im Spiegel des Mikrozensus. Eine Kohortenanalyse der Mikrozensen 1987 bis 2003. Wirtschaft und Statistik (8), 800-820.

Hagestad, G. O., \& Call, V. R. A. (2007). Pathways to childlessness. A life course perspective. Journal of Family Issues, 28, 1338-1361.

Hajnal, J. (1965). European marriage patterns in perspective. In D. V. Glass \& D. E. C. Eversley (Eds.), Population in history: Essays in historical demography (pp. 101-143). London: Edward Arnold.

Hoem, J. M., \& Kreyenfeld, M. (2006). Anticipatory analysis and its alternatives in life-course research. Part 2: Two interacting processes. Demographic Research, 15, 485-498.

Huinink, J., Brüderl, J., Nauck, B., Walper, S., Castiglioni, L., \& Feldhaus, M. (2011). Panel analysis of intimate relationships and family dynamics (pairfam): Framework and design of pairfam. Zeitschrift für Familienforschung, 23, 77-101.

Huinink, J., Kreyenfeld, M., \& Trappe, H. (Eds.). (2012). Familie und Partnerschaft in Ost- und Westdeutschland: Ähnlich und doch immer noch anders. Leverkusen: Babara Budrich.

Human Mortality Database. (2016). West Germany, Population size (1-year). In V. Shkolnikov, M. Barbieri, \& J. Wilmoth (Eds.), http://www.mortality.org/

Jalovaara, M., \& Fasang, A. E. (2015). Are there gender differences in family trajectories by education in Finland? Demographic Research, 33, 1241-1256.

Knodel, J. (1967). Law, marriage and illegitimacy in nineteenth-century Germany. Population Studies, 20, 279-294.

Konietzka, D. (2003). Vocational training and the transition to the first job in Germany. New risks at labor market entry? In D. Bills (Ed.), The sociology of job training. Research in the sociology of work (pp. 161-195). Amsterdam: Elsevier.

Kreyenfeld, M. (2002). Parity specific birth rates for West Germany: An attempt to combine survey data and vital statistics. Zeitschrift für Bevölkerungswissenschaft, 27, 327-357.

Kreyenfeld, M., Huinink, J., Trappe, H., \& Walke, R. (2012). DemoDiff: A dataset for the study of family change in Eastern (and Western) Germany. Schmollers Jahrbuch, 132, 653-660.

Lois, D. (2010). Wie verändert sich die Religiosität im Lebensverlauf? Eine Panelanalyse unter Berücksichtigung von Ost-West-Unterschieden. Kölner Zeitschrift für Soziologie und Sozialpsychologie, 63, 83-110.

Matz, K.-J. (1980). Pauperismus und Bevölkerung: Die gesetzlichen Ehebeschränkungen in den süddeutschen Staaten während des 19. Jahrhunderts. Stuttgart: Klett-Cotta.

Mitterauer, M. (1990). Servants and youth. Continuity and Change, 5, 11-38.

Naderi, R. (2015). Kinderzahl und Migrationshintergrund. Ein Vergleich zwischen Frauen türkischer Herkunft mit oder ohne eigene Wanderungserfahrung sowie Frauen ohne Migrationshintergrund in Westdeutschland. Zeitschrift für Familienforschung, 3, 322-342.

Nave-Herz, R. (2006). Ehe- und Familiensoziologie. Weinheim/München: Juventa.

Rendall, M. S., Clarke, L., Peters, H. E., Ranjit, N., \& Verropoulou, G. (1999). Incomplete reporting of men's fertility in the United States and Britain: A research note. Demography, 36, 135-144.

Rupp, M. (2005). Kinderlosigkeit in stabilen Ehen. Zeitschrift für Familienforschung, 17, 21-40. 
Schmitt, C., \& Winkelmann, U. (2005). Wer bleibt kinderlos? Was sozialstrukturelle Daten über Kinderlosigkeit bei Frauen und Männern verraten. Zeitschrift für interdisziplinäre Frauen- und Geschlechterforschung, 23, 9-23.

Schwarz, K. (1991). Die Kinderzahl der Frauen der Geburtsjahrgänge 1865-1955. Zeitschrift für Bevölkerungswissenschaft, 17, 149-157.

Zeeb, F. B. (1915). The mobility of the German woman. American Journal of Sociology, 21.

Open Access This chapter is distributed under the terms of the Creative Commons Attribution 4.0 International License (http://creativecommons.org/licenses/by/4.0/), which permits use, duplication, adaptation, distribution and reproduction in any medium or format, as long as you give appropriate credit to the original author(s) and the source, provide a link to the Creative Commons license and indicate if changes were made.

The images or other third party material in this chapter are included in the work's Creative Commons license, unless indicated otherwise in the credit line; if such material is not included in the work's Creative Commons license and the respective action is not permitted by statutory regulation, users will need to obtain permission from the license holder to duplicate, adapt or reproduce the material.

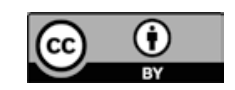

